Research Article

\title{
Nutritional, Hypoglycemic, and Haematinic Potentiality of Edible Mushroom Pleurotus tuber-regium (Rumph. ex Fr.) Singer
}

\author{
Sukumar Dandapat ${ }^{1}$, Manoj Kumar ${ }^{2}$, Rakesh Ranjan ${ }^{1}$, Manoranjan Prasad Sinha ${ }^{1}$ \\ ${ }^{1}$ Department of Zoology, Faculty of Sciences, Ranchi University, Ranchi 834008, India \\ ${ }^{2}$ Department of Zoology, Faculty of Sciences, St. Xavier's College, Ranchi 834001, India
}

Article history:

Submission March 2019

Revised June 2019

Accepted July 2019

*Corresponding author:

E-mail: dr.sukumar2018@gmail.com

\begin{abstract}
Mycochemical composition, calorific value, the antioxidant activity of Pleurotus tuber-regium was analyzed and impact of $P$. tuber-regium extract on rat model especially glycemic, vitamins and blood parameters were explored to validate its medicinal importance. Mycochemical screening showed the presence of biochemicals such as phenols, flavonoids, proteins, carbohydrates etc. The extract showed good antioxidant activity (33.62\% total antioxidant activity equivalent to $21.30 \mu \mathrm{g}$ ascorbic acid). The extract showed dose -dependent hypoglycaemic activity by significant decreased average blood glucose level at high dose (100.62 \pm $1.04 \mathrm{mg} / \mathrm{dL})$ compare to control $(124.40 \pm 1.45 \mathrm{mg} / \mathrm{dL})$, haematinic activity by elevation of hemoglobin $(14.75 \pm 0.24 \mathrm{~g} / \mathrm{dL})$ at a high dose of extract compared to control $(11.66 \pm 0.21 \mathrm{~g} / \mathrm{dL})$. P. tuber-regium extract elevated vitamin B12 of rats at high dose of extract $(449.60 \pm 3.12 \mathrm{pg} / \mathrm{mL})$ compared to control $(420.00 \pm$ $2.86 \mathrm{pg} / \mathrm{mL}$ ). P. tuber-regium extract showed a positive response to hypoglycemic, haematinic, and vitamin level of the body and posses high calorific value. Hence $P$. tuber-regium can be used as good fodder, medicinal and nutritional supplement.
\end{abstract}

Keywords: Vitamin, mycochemicals, medicinal, antioxidant, diabetes

\section{Introduction}

In recent decades population explosion and its burden is directly associated with burden of noncommunicable diseases especially chronic and nonchronic disease such as diabetes, renal, cardiovascular, respiratory, cancer and conditions associated with malnutrition [1]. Worldwide in past two decades more than 57 million deaths occurred, and more than 29 million deaths occurred due to noncommunicable diseases in a developing country [2]. Diabetes and malnutrition are two major factors in developing countries related to morbidity and approximately 6 million people die every year due to diabetes $[3,4]$. It has been estimated and reported by WHO that, worldwide every year about 11 million death of population below 10 years age occurs due to nutritional deficiency diseases and disorders [5]. One of the major causes of diabetes is the production of free radicals (reac- tive oxygen and nitrogen species) impart deleterious effects and one of them is diabetes [6].

The leading causes of deficiency diseases in developing countries are due to low nutrient quality of food and deficiency to minerals, vitamins, and other nutrient proteins, fats [7]. In recent decades, annual population growth rate as well as the burden of disease in developing countries of the Middle East and Sub-Saharan Africa, Latin America, South Asia and Southeast Asia increasing continuously due to poverty, improper education, insufficient medicine and medical facility etc. [8]. The population growth in India for last 30 years have been increasing at the rate of $2.3 \%$ per year [9], and an emerging drastic environmental imbalance will lead wider spectrum of health risks, resource fulfilment such as nutritional diet, proper supply of medicine, etc. [10,11].

Traditionally mushrooms have been used as

\section{How to cite:}

Dandapat S, Kumar M, Ranjan R, Sinha MP (2019) Nutritional, Hypoglycemic, and Haematinic Potentiality of Edible Mushroom Pleurotus tuber-regium (Rumph. ex Fr.) Singer. Journal of Tropical Life Science 9 (2): 195 - 207. doi: 
medicine as well as excellent source of nutrient [12]. About 700 species of mushrooms have been reported for their significant therapeutic efficacy [13]. Medicinal mushrooms contain various mycochemicals such as tannins, alkaloids, flavonoids, phenolics, etc., which associated with the remedy of diseases and disorders. Pleurotus tuberregium (Rumph. ex Fr.) Singer, commonly called king oyster mushroom, has been traditionally consumed as medicine and nutraceutical food supplement [14].

The aim of the present work to study proximate biochemical composition with nutritional potentiality, antioxidant activity of $P$. tuber-regium and impact of $P$. tuber-regium extract on glycemic, vitamins and blood parameters of rat and to validate the nutritional potentiality of $P$. tuber-regium because the screening of medicinal effects of $P$. tuber-regium on mammalian model is least explored.

\section{Material and Methods Collection, identification of mushroom and prep- aration of extract}

Fresh fruiting bodies of $P$. tuber-regium were collected from different sites of three National Parks namely Orang National Park, Kaziranga National Park and Manas National Park of Assam and were identified in Department of Botany, Gauhati University, Guwahati, Assam and brought to Department of Zoology, Ranchi University, Ranchi form preparation of extract.

\section{Preparation of extract}

Fresh mushrooms were dried in the shade under room temperature for six to seven days, powdered and sieved. As much as $50 \mathrm{~g}$ of the fine powder was subjected to the extraction chamber of soxhlet using distilled water. The extracts obtained were filtered, concentrated dried in the rotary flash evaporator and the dried extract was stored in air tight containers at room temperature for further study.

\section{Mycochemical screening}

Qualitative analyses of proximate biochemical present in the extract of $P$. tuber-regium were determined following Arya et al. [15]. Presence of various biochemicals based on function groups were detected by FTIR spectroscopy (IPRresting21, Shimadzu). Quantitative estimation of tracea- ble biochemicals was done following Dandapat et al. [16].

\section{Nutritional potentiality}

Nutritional potentiality of $P$. tuber-regium fruiting body was estimated on the basis of total protein, fat and carbohydrate using methodology proposed by Nile and Cobragade [17].

\section{Antioxidant activity}

Antioxidant activity of $P$. tuber-regium extract was determined on the basis of total antioxidant activity [18], free radical scavenging and hydroxyl radical scavenging activity [19] using standard methods.

\section{Impact on rat model \\ Animals}

Wistar albino rats of 175 to $200 \mathrm{~g}$ were obtained from the National Institute of Nutrition, Hyderabad, India. They were maintained under standard laboratory conditions at ambient room temperature and relative humidity, with dark-light cycle of 12 hours. Animals were fed with a commercial pellet diet (Sadguru Shri Shri Industries Pvt. Ltd. Pune, India) and water. The experiment was performed after prior approval of the Ethics committee of Ranchi University, Ranchi (Proceeding no. 46, page no. 137).

\section{Acute toxicity studies}

Single doses of $P$. tuber-regium extract (2000 mg. $\mathrm{kg}^{-1}$ body weight) was administered orally by oral feeding gavage to rats. The animals were observed for gross behavior, neural, and autonomic toxicity as described on OECD guidelines [20].

\section{Experimental design}

Fifteen fresh animals were acquired and equally distributed among three treatment groups (Group: 1, 2 and 3) each group contain 5 animals. Low dose and a high dose of extract was calculated as per the guideline of OECD [20] and Oghenesuvwe et al. [21]. At the end of the experiment ( $8^{\text {th }}$ day) animals were anesthetized and blood was collected by orbital sinus blood sample collection method.

Group-1 (Control): rats were served as a control and were not treated with mushroom extract and received $1 \mathrm{~mL}$ of distilled water orally throughout the entire period of the experiment. 


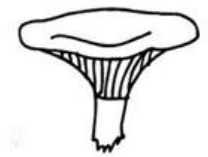

(a)

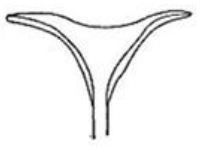

(b)

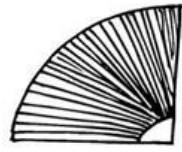

(c)

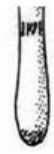

(d)
Figure 1. Diagrammatic morphological representation of $P$. tuber-regium: fruiting body (a), decurrent gill (b), crowded lamellae (c), and stipe (d)

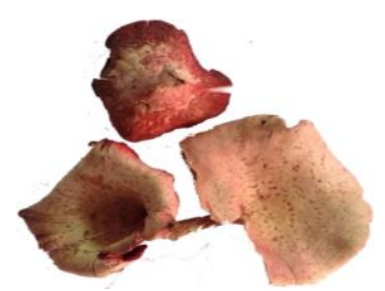

(a)

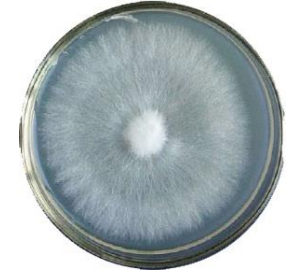

(b)
Figure 2. Photograph of collected $P$. tuber-regium fruiting bodies and grown mycelia from $P$. tuber-regium fruiting body

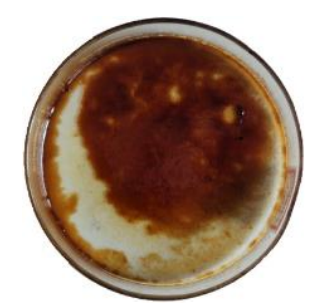

Figure 3. Aqueous extract of $P$. tuber-regium fruiting bodies

Group-2 (low dose): Rats were received 200 mg. $\mathrm{kg}^{-1}$ body weight considered as low dose of $P$. tuber-regium extract orally for 7 days. Group-3 (high dose): Rats were received $400 \mathrm{mg} . \mathrm{kg}^{-1}$ body weight considered as high dose of $P$. tuber-regium extract orally for 7 days.

\section{Estimation of HbA1c and average blood pressure (ABG)}

Percentage of HbA1c was estimated by using fully automated HPLC (Model - TOSOH G8). Average blood glucose was estimated from derived values from HbA1c [22].

\section{Estimation of vitamin $D$ and vitamin $B 12$}

The concentration of vitamin $\mathrm{D}$ and vitamin B12 in the serum samples were estimated by using fully automated chemiluminescent immune assay (25-OH Vitamin D IR (chemi luminescence immune assay) CLIA kit [23] and AccuBind Vitamin B-12 CLIA kits of Tosoh Bioscience's) and Tosoh
Bioscience's AIA-360 automated immunoassay analyzer [24].

\section{Hematologial analysis}

For haematological indices, blood samples were collected into sterile tubes containing EDTA and immediately analyzed for total white blood corpuscle count (TWBC), total red blood corpuscle count (TRBC), Hb, and mean corpuscles volume of RBC (MCV) using Sysmex automated blood analyzer - KX 21 Kobe, Japan.

\section{Statistical analysis}

Data were taken 5 times and results were expressed as a mean \pm standard error of the mean. Statistical analysis was performed using Student's t-test, $\mathrm{p}<0.05$ was considered as statistically significant. Entire statistical analyses were performed using full proof software WinSTAT.

\section{Results and Discussion Morphological of $P$. tuber-regium}

The fruiting body of the mushroom is cupshaped. Pileus is deeply infundibulate, incurved margin with deeply decurrently gills, smoky dark at center, pale and interrupted white villous form towards the margin presented in Figure 1. The pileus of the fruiting bodies is 3.4 to $7.2 \mathrm{~cm}$ in diameter presented in Figure 2. Stem or stipes is central, attached with gills, without annulus, sub cylindrical, slightly thick at base having underground tuber sclerotium (Figure 1). The stipeses are $2.5 \mathrm{~cm}$ to $6.3 \mathrm{~cm}$ long and $6 \mathrm{~mm}$ to $11 \mathrm{~mm}$ in diameter, minutely smoky or pale in color presented in Figure 2. Morphological identification of P. tuber-regium was done from collected fruiting body and matched with the description mention given in fungi database Mycobank and Encyclopedia of life $[25,26]$. In the present study sclerotiums were not collected and presented. Previously it has been reported $P$. tuber-regium (Singer.) grown on humus soil (HS), mixture of sawdust and humus soil (MSHS), sawdust (SD) had variable diameter of the pileus (HS: $7.74 \pm 2.18 \mathrm{~cm}$, MSHS: $8.65 \pm 1.75$ $\mathrm{cm}$, SD: $5.23 \pm 1.53 \mathrm{~cm}$ ) and variable length of stipe (HS: $6.72 \pm 1.44 \mathrm{~cm}$, MSHS: $5.83 \pm 0.47 \mathrm{~cm}$, SD: $4.83 \pm 0.77 \mathrm{~cm}$ ) [27]. Jonathan and Adeoyo also reported the morphological characteristics of $P$. tuber-regium. They reported, the collected fruiting bodies were creamy in colour, the caps were $5.6 \mathrm{~cm}$ in diameter and stalks were $5.6 \mathrm{~cm}$ in 
Table 1. Qualitative biochemical analysis of P. tuberregium extract

\begin{tabular}{lc}
\hline \multicolumn{1}{c}{ Mycochemicals } & Present (+) or Absent (-) \\
\hline Carbohydrate & + \\
Glycosides & + \\
Protein & + \\
Alkaloid & + \\
Steroid & + \\
Triterpene & + \\
Flavonoid & + \\
Tannin & - \\
Lipid & + \\
Saponin & + \\
\hline
\end{tabular}

length [28].

\section{Mycochemical screening}

The result of the qualitative screening of biochemical present in P. tuber-regium extract (Figure 3) presented in Table 1 . The biochemical screening of extract shows the presence of different mycochemicals such as carbohydrates, glycosides, proteins, tannins, saponins, alkaloids, steroids, and lipids. Confirmation of presence of mycochemicals in the extract was done by FTIR spectroscopy analysis. The FTIR spectrum of $P$. tuberregium is presented in Figure 4. The result of FTIR analysis shows major absorption peaks at 3,290 $\mathrm{cm}^{-1}$, represents $\mathrm{O}-\mathrm{H}$ stretch for alcohol and phenols, 2,935 $\mathrm{cm}^{-1}$ represents $\mathrm{N}-\mathrm{H}$ and N-H stretch for amino acids, carboxylic acid and its derivatives, $1,658 \mathrm{~cm}^{-1}$ represents $\mathrm{C}=\mathrm{C}$ stretch for alkane, $1,600 \mathrm{~cm}^{-1}$ represents $\mathrm{C}=$ stretch for aromatic compounds, $1,392 \mathrm{~cm}^{-1}$ stretch for O-H represents phenolic compound, $1,041 \mathrm{~cm}^{-1}$ represents C-X stretch for chloroalkanes, $945 \mathrm{~cm}^{-1}$ represents $\mathrm{C}-\mathrm{H}$ and P-OR stretches for aromatic and phosphate group respectively and $520 \mathrm{~cm}^{-1}$ represents $\mathrm{C}-\mathrm{Br}$ or C-I or S-S stretch. Result of qualitative biochemical analysis of traceable mycochemical is presented in Figure 5. Among the mycochemicals alkaloid was found significantly ( $\mathrm{p}<0.05)$ high quantity $(28.14 \pm 0.32 \mathrm{mg} / 100 \mathrm{~g})$ and tannin significantly $(\mathrm{p}<0.05)$ low quantity $(2.74 \pm 0.26$ $\mathrm{mg} / 100 \mathrm{~g}$ ) among all the studied biochemicals.

Mushroom contains various types of biochemicals such as phenols and flavonoids, tannins, proteins, polysaccharides etc. Previously preliminary biochemical screening of edible white button mushroom Agaricus bisporus was done and presence of biochemical such as saponins, tannins, glycosides, reducing sugar, alkaloid, flavonoid, terpenoid etc. were reported [29]. FTIR analysis provides the confirmation about functional groups different mycocheicals [30-32]. In previous study FTIR analysis of crude extract of Lentinula edodes, Pleurotus ostreatus, and Agaricus blazei were done and reported stretches of absorption spectra of 3,600 $\mathrm{cm}^{-1}$ and 3,200 $\mathrm{cm}^{-1}$ for O-H corresponds sugar residue, 2,980 $-2,840 \mathrm{~cm}^{-1}$ represents $\mathrm{C}-\mathrm{H}$ stretching, $1,200-900 \mathrm{~cm}^{-1}$ corresponds to of carbohydrates and stretching vibrations of $\mathrm{C}-\mathrm{C}, \mathrm{C}-\mathrm{O}-\mathrm{C}$ for glucopyranose and $\mathrm{C}-\mathrm{O}$, $1,640 \mathrm{~cm}^{-1}$ and $1,530 \mathrm{~cm}^{-1}$ for amides for the confirmation of presence of biochemicals such as saponins, tannins, glycosides, reducing sugar, alkaloid, flavonoid, terpenoid etc. [33].

It has been reported other mushroom also contain $64.12 \pm 1.2 \mathrm{mg} / \mathrm{g}$ phenols, $0.016 \pm 0.001 \mathrm{mg} / \mathrm{g}$ flavanoid, $0.28 \pm 0.04 \mathrm{mg} / \mathrm{g}$ saponins, $0.1 \pm 0.04 \%$ alkaloids and $0.014 \pm 0.003 \%$ tannins in Tricholoma nudum and $6.012 \pm 0.91 \mathrm{mg} / \mathrm{g}$ phenols, $0.031 \pm 0.02 \mathrm{mg} / \mathrm{g}$ flavanoids, $0.27 \pm 0.008 \mathrm{mg} / \mathrm{g}$ saponins, $2.0 \pm 0.01 \%$ alkaloids and $0.014 \pm 0.001$ $\%$ tannins in Psalliota campestris and the biochemicals possess therapeutic efficacy [34]. Biochemicals such as phytophenols, flavonoids, tannins, saponins, etc. are associated with the reduction of free radicals and decrease the risks of disease and disorders associated with oxidative stress [35, 36]. In the present study FTIR analysis (Figure 4) of P. tuber-regium extract also confirmed mycochemicals such as phenols, amines, carbohydrates, etc.

\section{Antioxidant activity}

Antioxidant activity of $P$. tuber-regium was determined on the basis of free radical scavenging, hydroxyl radical scavenging capacity and total antioxidant activity of the mushroom extract. Results of antioxidant activity of $P$. tuber-regium are presented in Figure 6, 7, and 8. BHA (Butylated Hydroxy Anisole) is a synthetic reducing agent and its free radical scavenging activity is quite higher than the extract presented in Figure 6. However, the extract also shows good free radical scavenging activity.

As much as $100 \mu \mathrm{g} / \mathrm{mL}$ of extract showed significantly $(\mathrm{p}<0.05)$ highest free radical scavenging activity (8.98 $\pm 1.02 \%)$ among the tested con- 


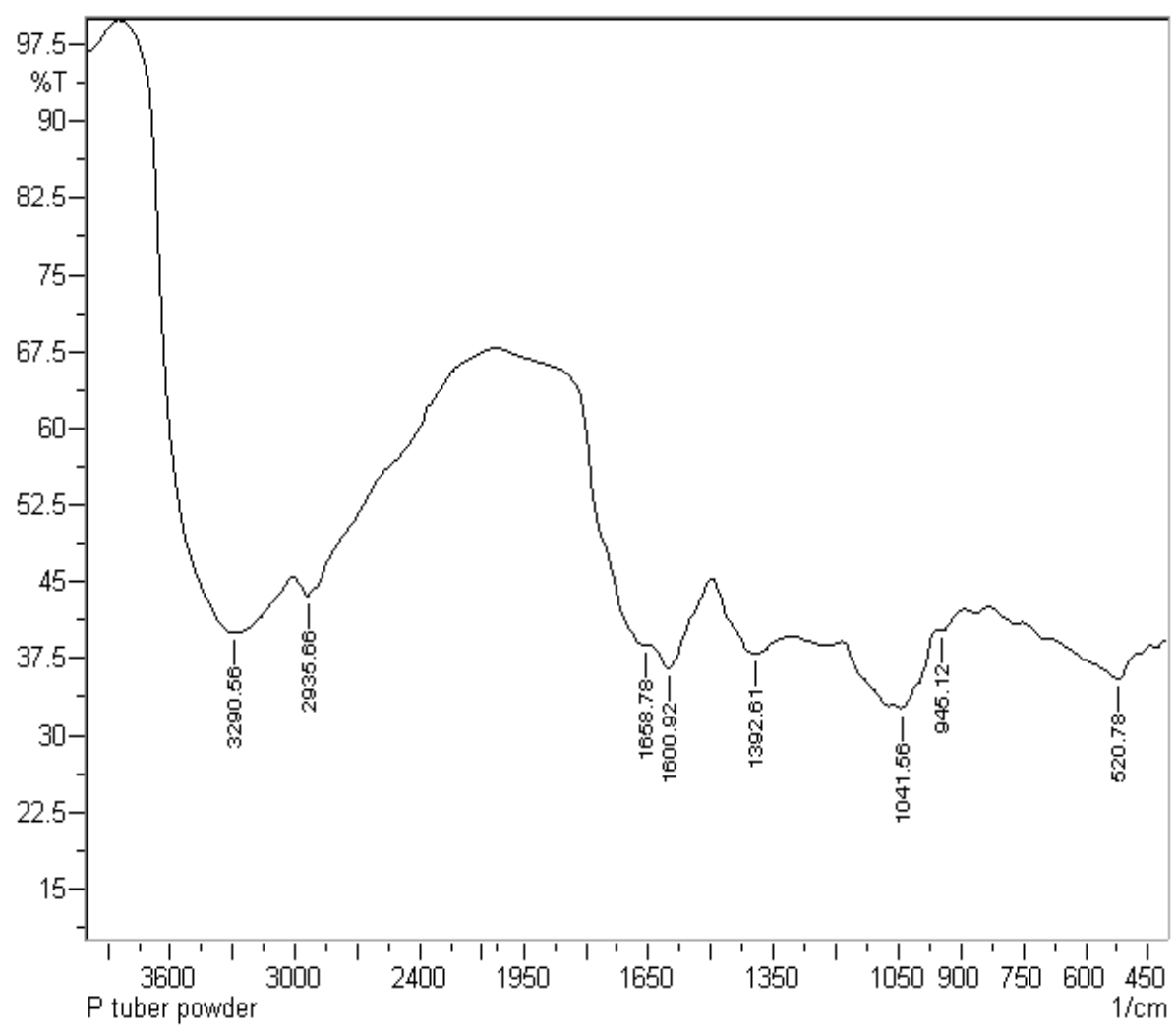

Figure 4. FTIR spectra analysis of P. tuber-regium extract

Table 2. Nutritional value of $P$. tuber-regium, $\mathrm{n}=5 \pm \mathrm{SE}$, $*=\mathrm{p}<0.05$, ***= $<0.0005$

\begin{tabular}{lrrrr}
\hline \multicolumn{2}{c}{ Nutritional components (g\%) } & \multicolumn{2}{c}{ Nutritional value } \\
\hline Crude protein & Crude carbohydrate & \multicolumn{1}{c}{ Crude fat } & Crude fiber & Calorific value (Cal/100g) \\
\hline $10.54 \pm 0.70^{*, * * *}$ & $58.24 \pm 2.89^{* * *}$ & $2.53 \pm 0.37^{*, * * *}$ & $8.64 \pm 0.66^{* * *}$ & $297.89 \pm 15.92$ \\
\hline
\end{tabular}

centrations of the extract. Hydroxy radical scavenging activity of the extract was compared with ascorbic acid (presented in Figure 7) and found $100 \mu \mathrm{g} / \mathrm{mL}$ of the extract showed significantly (p $<0.05)$ highest $(10.85 \pm 0.73 \%)$ hydroxyradical scavenging activity among the tested extract but the ascorbic acid showed significantly $(\mathrm{p}<0.05)$ more effective scavenging activity (68.11 \pm $2.46 \%$ ). Total antioxidant capacity of the crude extract (presented in Figure 8) showed significantly $(p<0.05)$ very effective result. As much as 100 $\mu \mathrm{g} / \mathrm{mL}$ extract showed $21.50 \pm 1.3 \%$ antioxidant activity equivalent to ascorbic acid when compared to the same concentration of BHA (65 \pm $1.5 \%$ antioxidant activity). However, $10 \mu \mathrm{g} / \mathrm{mL}$ extract did not show any activity.

Antioxidants are chemicals mainly derivative of plants or mushrooms that reduces free radicals such as $\mathrm{O}_{2}^{-}, \mathrm{OH}^{-}, \mathrm{Fe}^{2+}$ or $\mathrm{Fe}^{3+}$ etc. [37]. Previously antioxidant activity of Pleurotus florida and Calocybe indica was studies and reported hydroxyl radical scavenging of extracts of $P$. florida and $C$. indica $65.41 \pm 0.65 \%$ at $1,000 \mu \mathrm{g} / \mathrm{mL}$ and $46.99 \pm$ $2.58 \%$ at $1,000 \mu \mathrm{g} / \mathrm{mL}$ respectively [38]. It has been reported antioxidant activity of plant and mushroom extracts are concentration dependent, and the antioxidant activity depends upon the concentration of bioactive mycochemicals such as alkaloids, tannins, saponins, flavonoids, phenols, etc. present in the fruiting body of mushrooms [39]. It has also been reported bioactive chemicals including primary and secondary metabolites of plant and mushroom origin possess reducing power and reduces the reactive oxygen and nitrogen species produced in the human body during pathogenic infections, so that they can act as a source of good and safe antioxidants [40, 41]. 


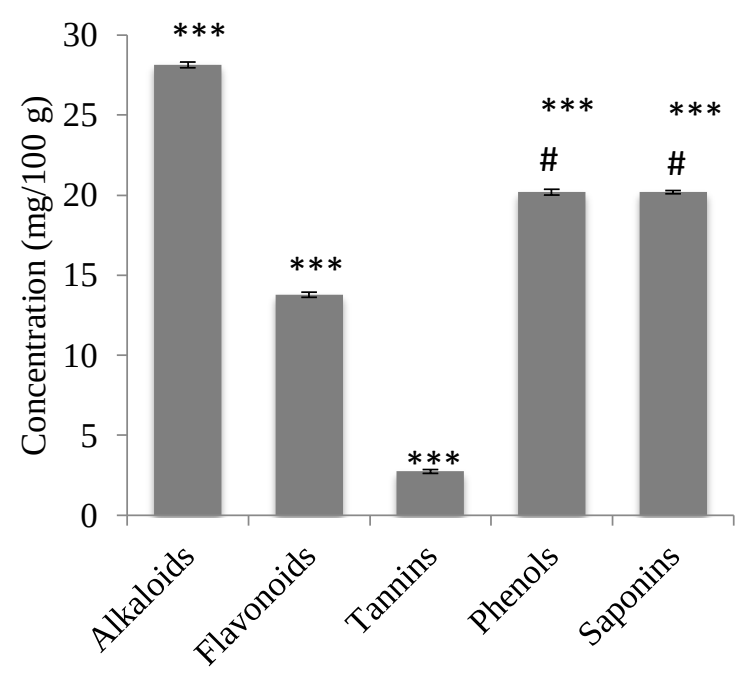

Mycochemicals

Figure 5. Qualitative analysis of traceable biochemical of $P$. tuber-regium, $\mathrm{n}=5 \pm \mathrm{SE}, * * *=\mathrm{p}$ $<0.0005$, \# = No significant differences between phenol and saponin

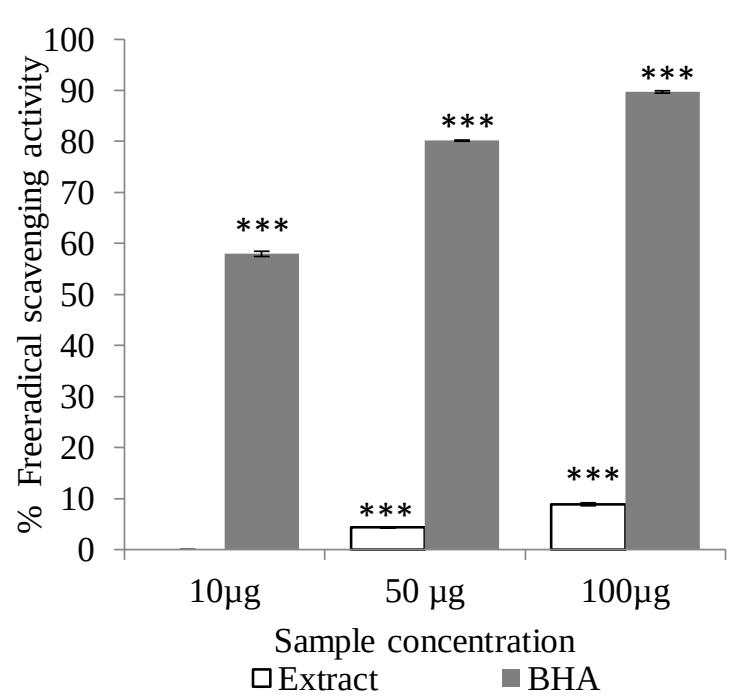

Figure 6. Free radical scavenging activity of $P$. tuberregium extract $\mathrm{n}=5 \pm \mathrm{ES}, * * *=<0.0005$

\section{Nutritional potentiality}

In the present study, nutritional value of $P$. tuber-regium is presented in Table 2 . The result shows carbohydrate content significantly ( $\mathrm{p}<$ 0.05 ) high and fat content is significantly ( $p<$ 0.05 ) low among the nutritional components. It has been reported that mushrooms are rich in nutritional constituents such as proteins, minerals, vitamins, fiber and carbohydrate with low-fat content but mushroom has twice higher protein content than vegetables and four times than cereals [42]. Thatoi and Singdevsachan [43] studied the

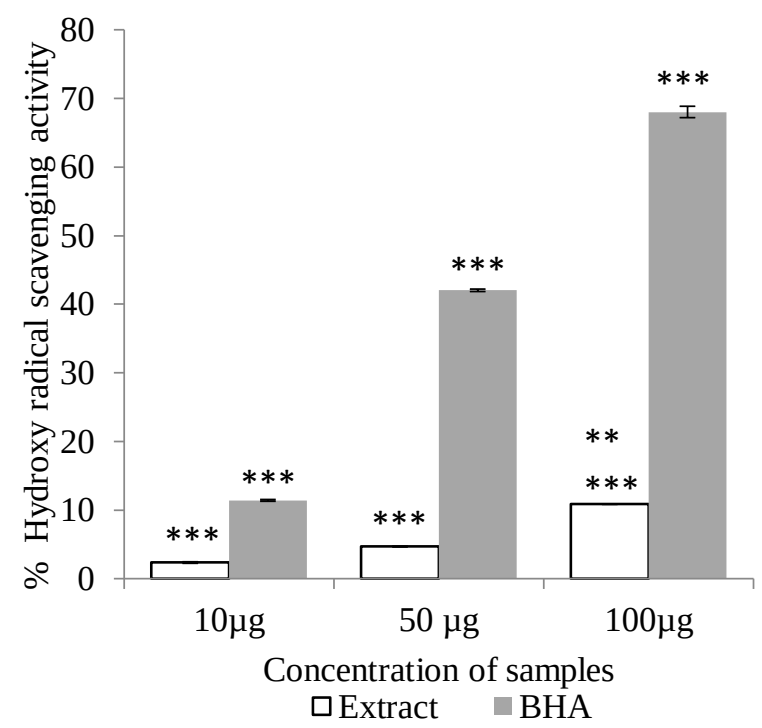

Figure 7. Hydroxyl radical scavenging activity of $P$. tuber-regium extract $\mathrm{n}=5 \pm \mathrm{ES}, * *=\mathrm{p}<$ $0.0025, * * *=<0.0005$

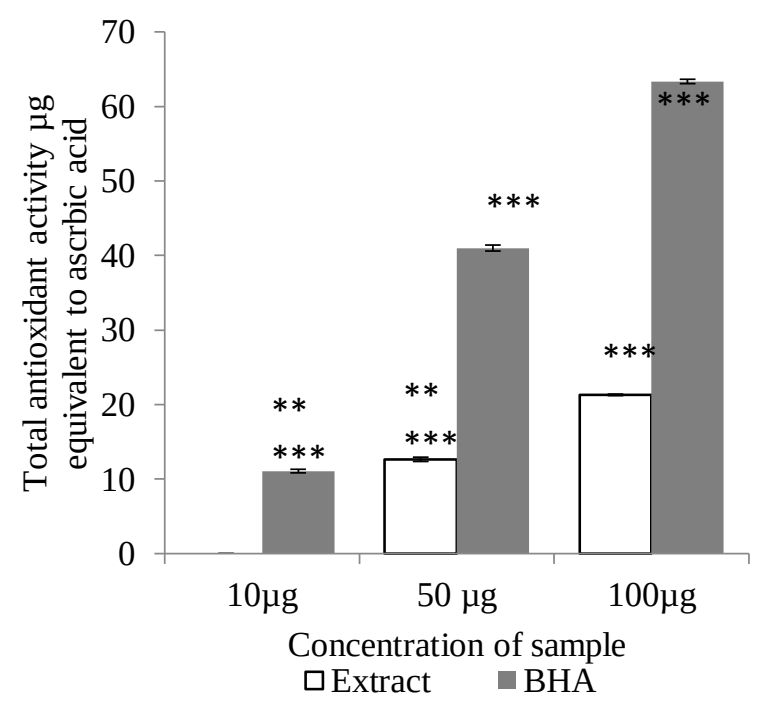

Figure 8. Total antioxidant capacity of P. tuber-regium extract, $\mathrm{n}=5 \pm \mathrm{ES}, * *=\mathrm{p}<0.005$, ***= $<0.0005$

nutritional composition of eight Pleurots spp. and reported carbohydrate content (32 - 63\%) was higher than protein content $(19-39 \%)$. They also reported the mushroom species to contain very low fat $(1-3 \%)$ and good edible fibre $(4-48 \%)$. Edible mushrooms contain almost all the essential and non-essential amino acids which are associated with maintenance of the antioxidant system of the body [44]. In a previous study, it has been reported edible mushrooms contains a high amount of protein and carbohydrates with very 
low lipid content (Table 2).

\section{Impact of the extract on rat}

Rats were treated with extract of P. tuber-regium for acute oral toxicity test did not show any morbidity and toxic effects such as convulsion, hair loss, nausea etc. hence the extract of $P$. tuberregium is safe for long term use. Results of impact of extract of $P$. tuber-regium on rat for evaluation nutritional potentially has been studied and reported under following sub-heads.

\section{Impact of extract on the glycemic regulation}

Impact of $P$. tuber-regium extract on glycemic parameters of rats is presented in Figure 9 and 10. The extract significantly $(\mathrm{p}<0.05)$ decreased the HbA1c of high dose group rats $(2.40 \pm 0.43 \%)$ compare to low dose $(4.03 \pm 0.65 \%)$ and control group of rats (5.57 $\pm 0.67 \%)$. However, a non-significant decreased of HbA1c was observed in rats of low dose group compared to control group. $P$. tuber-regium extract showed good hypoglycaemic activity on both low and high dose groups of rats. The extract showed significant decrease $(\mathrm{p}<0.05)$ in average blood glucose level of both low (109.63 $\pm 1.40 \mathrm{mg} / \mathrm{dL}$ ) and high dose groups of rats (100.62 $\pm 1.04 \mathrm{mg} / \mathrm{dL})$ compare to control group (124.40 $\pm 1.45 \mathrm{mg} / \mathrm{dL})$.

It has also been reported that free radicals and oxidative stress directly associated with the development of diabetes [18]. HbAc1 and average blood glucose are two major indices to screening, diagnosis and prediction of progression of glycemia and there is a positive correlation between HbAc1 and blood glucose level [45, 46]. It has been reported medicinal mushrooms have been used as a traditional source of potential hypoglycemic and anti-diabetic agent and the mushrooms contain natural bioactive compounds such as polysaccharides, proteins, dietary fibers, and alkaloid, saponins, phenols, flavonoids, tannins, etc. [41, 47].

Several studies have been reported that, different biochemical have different mechanism to regulate and decrease blood glucose level [48]. Flavonoids either mimic as insulin or regulate the expression of enzymes involved in carbohydrate metabolism path way which enhance glucose uptake in tissues [49]. Odoh and Ezugwu [50] reported that, alkaloids increase glucose uptake in muscle by inhibiting expression of protein tyrosine phos-
phatase-1B of the insulin signaling pathway. Tannins are associated with glucose uptake from blood to muscles and other tissues by inducing translocation of the glucose transporter GLUT-4 and phosphorylation of the insulin receptors [51]. It has been also reported that saponins reduce serum glucose levels in old age diabetic patients [48, 52]. It has been reported mushroom belongs to genus Pleurotus possess antidiabetic activity [47]. Jayasuriya et al. [53] studied the oral hypoglycaemic activity of Pleurotus ostreatus (P.o.) and P. cystidiosus (P.c.) mushrooms on normal and diabetic rats and reported that, both the mushrooms significantly $(\mathrm{p}<0.05)$ reduced the serum glucose levels of normal and diabetic rats. Khatun et al. [54] studied the hypoglycemic activity of $P$. florida in rat and reported the mushroom powder significantly decreases blood glucose level of rat without any toxic effect. In present P. tuber-regium also shows similar result.

\section{Impact of extract on vitamin $D$ and vitamin B12}

Results of $P$. tuber-regium extract on vitamin $D$ and vitamin B12 level of the rat are presented in figure- 11 and 12, respectively. P. tuber-regium extract significantly $(\mathrm{p}<0.05)$ elevated the vitamin D level of high dose group of rats (33.05 \pm $3.08 \mathrm{ng} / \mathrm{dL}$ ) compare to low dose group (23.27 \pm $2.46 \mathrm{ng} / \mathrm{dL})$ and control group $(18.18 \pm 1.92$ $\mathrm{ng} / \mathrm{dL}$ ). However, a non-significant increase in vitamin D was observed in low dose group of rats compared to control rat group. Mushrooms are one of the best sources of vitamins especially Vitamin $B, C$, and D [55, 56]. Vitamin D is an essential vitamin for human health. It has been reported that food with rich vitamin D and additional vitamin D supplementation reduces risks of cerebrovascular, chronic kidney disease and increase insulin sensitivity [57]. Jasinghe et al. [58] studied bioavailability of the vitamin D-enriched mushrooms Lentinula edodes on rat model and found bone mineral density and serum calcium concentrate of the experimental group of rats was significantly higher ( $\mathrm{p}<0.01)$ than the control group.

The extract also showed a good result of vitamin B12. A significant increase $(p<0.05)$ in vitamin B12 level of Rats treated with high dose of the extract $(449.60 \pm 3.12 \mathrm{pg} / \mathrm{mL})$ was observed compare to low dose group $(443.60 \pm 2.37 \mathrm{pg} / \mathrm{mL})$ and control group $(420.00 \pm 2.86 \mathrm{pg} / \mathrm{mL})$ but a nonsignificant increase was observed in high dose 


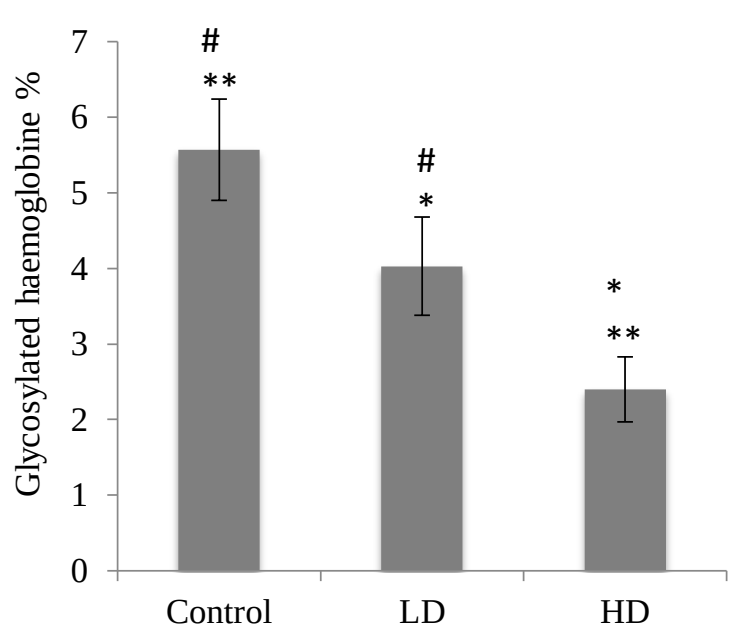

Rat groups treated with extract

Figure 9. Impact of $P$. tuber-regium extract on glycosylated haemoglobin (HbA1c) $\%, n=5 \pm S E$, \# = No significant differences between control and low dose, $*=\mathrm{p}<0.05, * *=\mathrm{p}<$ 0.0025 .

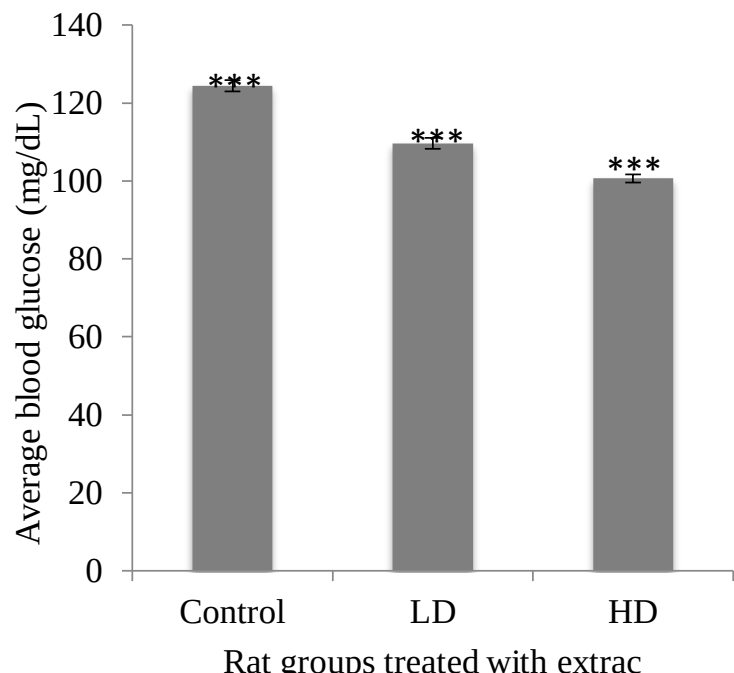

Figure 10. Impact of $P$. tuber-regium extract on ABG, $\mathrm{n}=5 \pm \mathrm{SE}, * * *=<0.0005$.

group compared to low dose group. It has been reported that food with rich vitamin B12 supplement is associated with maintenance of immune response of body [59]. It was also found significant ( $p<0.001)$ decrease in cytotoxicity mediated by natural killer cell [59]. Shawabkeh and Jamal [60] reported that in diabetic patients concentration of vitamin B12 is lower compared to healthy persons. No previous study has been reported on impact of mushroom extract on vitamin B12 and vitamin D level of rats but in present study, $P$. tuber-regium extract significantly $(\mathrm{p}<0.05)$ elevate vitamin

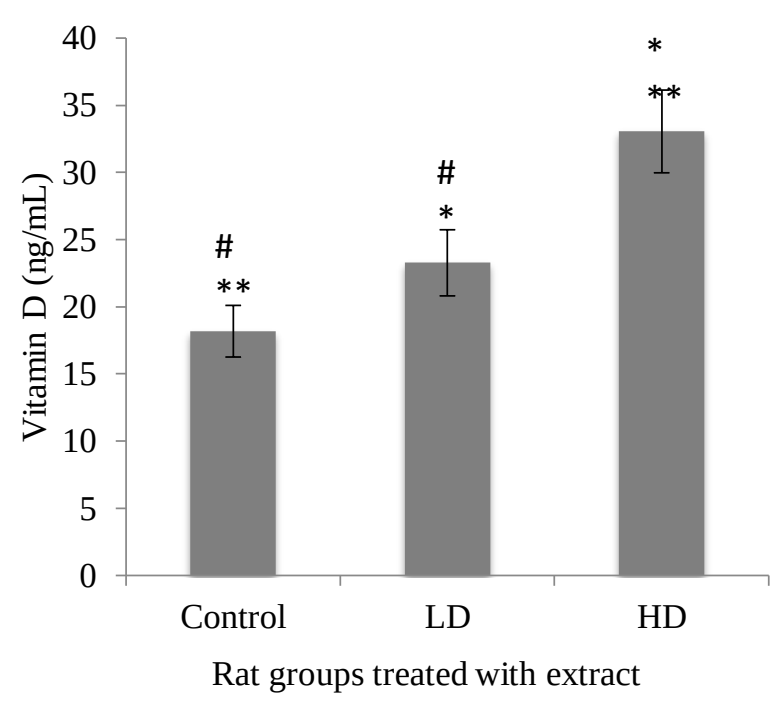

Figure 11. Impact of $P$. tuber-regium extract on vitamin $\mathrm{D}, \mathrm{n}=5 \pm \mathrm{SE}, \#=$ No significant differences between control and low dose, $*=p<0.02$, $* * \mathrm{p}=<0.0025$.

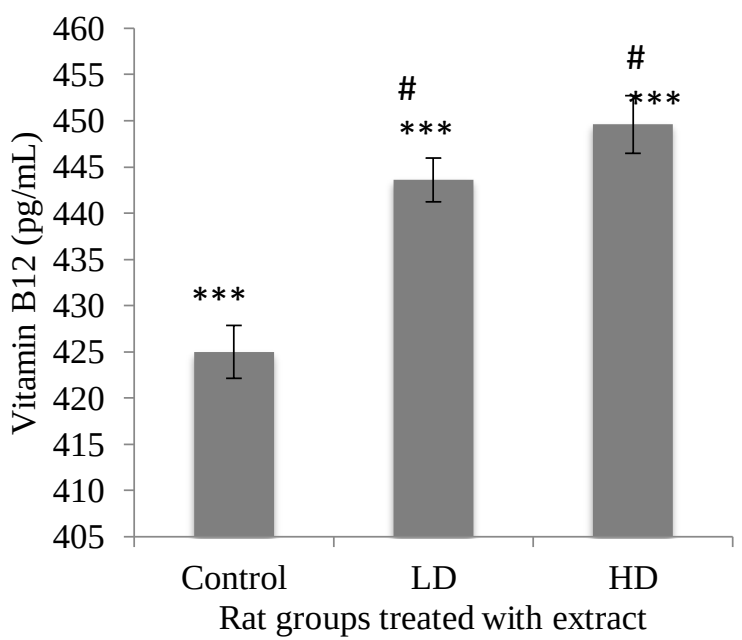

Figure 12. Impact of $P$. tuber-regium extract on vitB12, $n=5 \pm$ SE, \#=No significant differences between low dose and high dose, $* * *=<$ 0.0005

B12 concentration both in high and low dose group (Figure 12) which were associated with glycemic parameters of rats and must be enhanced immunity of body.

\section{Impact of extract on haematological parameters of rat}

$P$. tuber-regium extract enhanced haematopoiesis in rats. Total RBC, haemoglobin concentration and total WBC count of high dose group $\left(\mathrm{RBC}=7.05 \pm 0.43 \times 10^{6} / \mu \mathrm{L}, \mathrm{Hb}=14.75 \pm 0.24\right.$ $\mathrm{g} / \mathrm{dL}, \mathrm{WBC}=8.35 \pm 0.31 \times 10^{3} / \mu \mathrm{L}$ ) significantly 


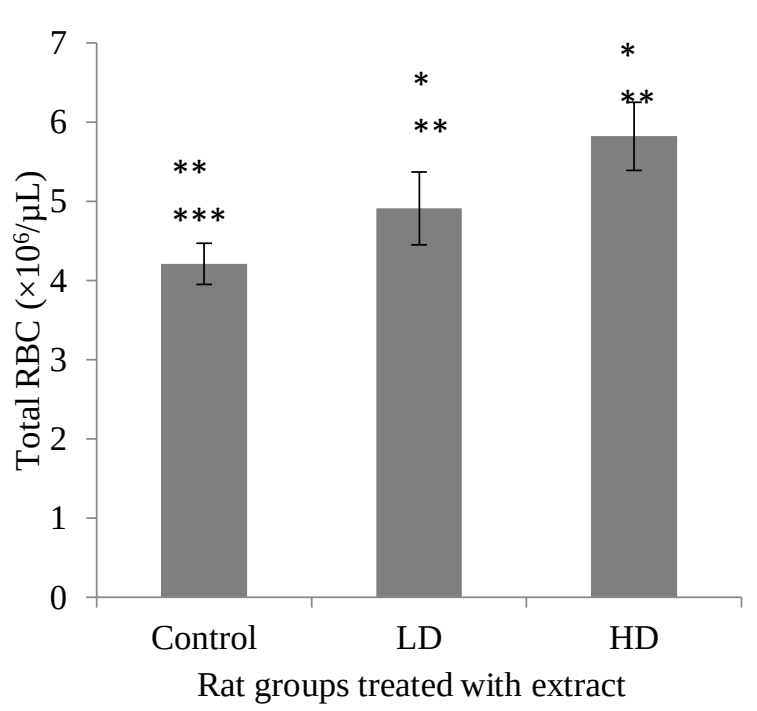

Figure 13. Impact of $P$. tuber-regium extract on total $\mathrm{RBC}\left(\times 10^{6} / \mu \mathrm{L}\right), \mathrm{n}=5 \pm \mathrm{SE}, *=\mathrm{p}<0.05, * *$ $=<0.005$, *** $=<.00005$.

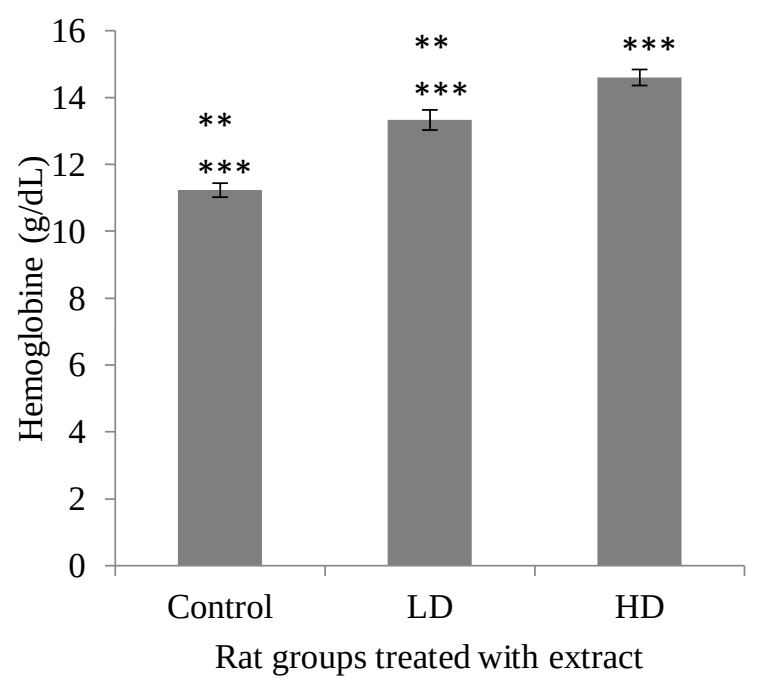

Figure 14. Impact of $P$. tuber-regium extract on $\mathrm{Hb}, \mathrm{n}=$ $5 \pm \mathrm{SE}, * *=\mathrm{p}<0.02, * * *=\mathrm{p}<0.0005$.

$(\mathrm{p}<0.05)$ increased compare to low $((\mathrm{RBC}=5.83$ $\pm 0.46 \times 10^{6} / \mu \mathrm{L}, \mathrm{Hb}=12.73 \pm 0.30 \mathrm{~g} / \mathrm{dL}, \mathrm{WBC}=$ $\left.7.54 \pm 0.22 \times 10^{3} / \mu \mathrm{L}\right)$ and control group $(\mathrm{RBC}=$ $4.12 \pm 0.02 \times 10^{6} / \mu \mathrm{L}, \mathrm{Hb}=11.66 \pm 0.21 \mathrm{~g} / \mathrm{dL}$, $\mathrm{WBC}=6.80 \pm 0.20 \times 10^{3} / \mu \mathrm{L}$ ). However, a non-significant increase in MCV was observed in high dose group (93.12 $\pm 0.25 \mu \mathrm{L}$ ) and low dose group $(93.07 \pm 0.33 \mu \mathrm{L})$ compare to control group $(93.00$ $\pm 0.15 \mu \mathrm{L})$.

Hematological parameters are usually associated with health status and are of diagnostic importance in clinical assessment and they are good indicators of the physiological, pathological, nu-

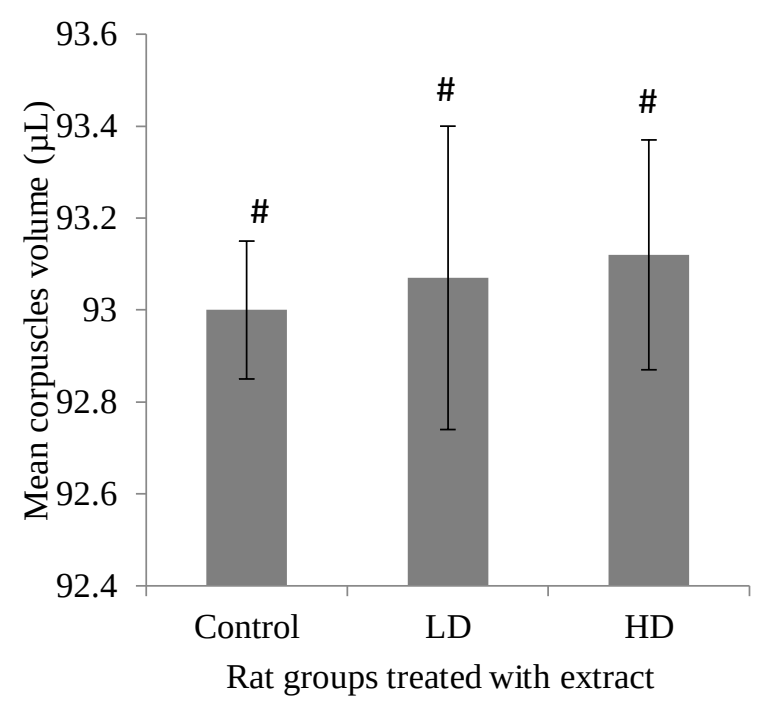

Figure 15. Impact of $P$. tuber-regium extract on mean corpuscles volume (MCV), $\mathrm{n}=5 \pm \mathrm{SE}$, \# = Non significant differences among the groups of rats.

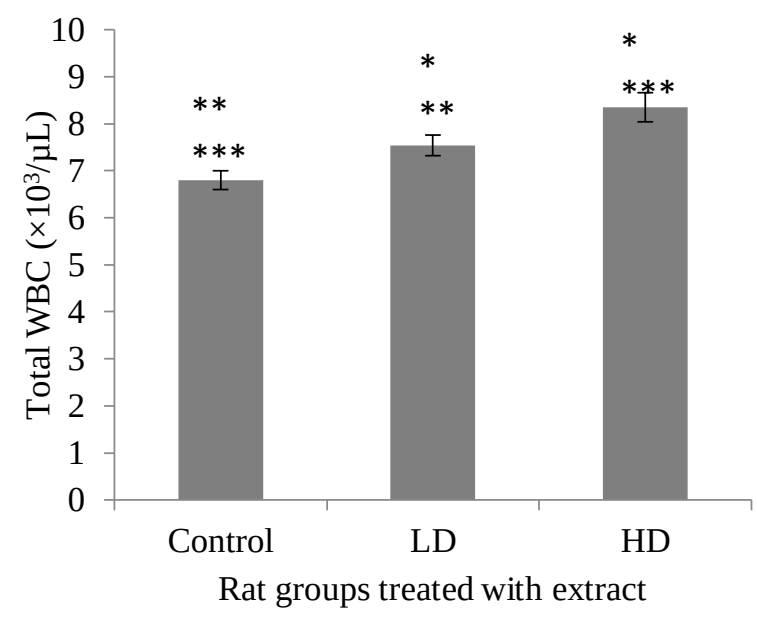

Figure 16. Impact of $P$. tuber-regium extract on total WBC $\left(\times 10^{3} / \mu \mathrm{L}\right), \mathrm{n}=5 \pm \mathrm{SE}, *=\mathrm{p}<0.05$, $* *=\mathrm{p}<0.025, * * *=\mathrm{p}<0.0025$.

tritional and immunological status of the body [61, 62]. Previously it was reported rats feed with mushroom extract of edible Plurotus species $(P$. ostreatus and $P$. pulmonarius) enhance the total RBC and WBC count, hemoglobin concentration and PCV in treatment group compared to nontreatment group [63]. Previously impact of $P$. florida on hematological parameters such as RBC count, $\mathrm{Hb}$ concentration and MCV of cadmium toxicity rats fed with $P$. florida supplement diet was studied and reported $P$. florida can prevent cadmium toxicity, maintain these parameters and enhance the level of these parameters [64]. In pre- 
sent study $P$. tuber-regium extract significantly (p $<0.05$ ) increased RBC count (Figure 13) and Hb concentration (Figure 14) of treated groups which may be due to enhancement of erythropoiesis in myeloid tissues of body, proper absorption of iron from food and their incorporation in hemoglobin molecules during their synthesis [65]. MCV is a measure of the average volume or size of a red blood cell. In the present study non-significant increase in MCV of both the treatment groups (Figure 15) was observed which may be due to increase in vitamin B concentration [66]. White blood cells count and its indices play a vital role in immune function and they are formed from pluripotent myelogenous tissue and are associated with immunity to the body against antigen invasion [65].

It has been reported mushroom belongs to Plurotus spp. possess immunomodulatory properties [14]. Previously it has been studied and reported feeding of $P$. ostreatus extracts significantly increase in the number of total white blood cells of Rainbow trout [69]. Similar study has been done to investigate immunomodulatory activity of oyster mushroom Pleurotus sajor-caju on mice. The result of this study reveals mice treated with various concentrations of P. sajor-caju significantly increased populations of cluster of differentiation molecule for immunophenotyping of cells (CD) molecules specially $\mathrm{CD}^{+} / \mathrm{CD}^{+}$, CD8 and WBC cells. It has also been reported Pleurotus mushroom contains non cellulosic fibers associated with effectively growth of probiotic and that encourage the growth of beneficial microorganisms in the gastro intestinal tract [68]. It has also been reported that intestinal microbe flora is the endogenous source of vitamin b in human [69, 70]. In the present study $P$. tuber-regium extract significantly $(\mathrm{p}<0.05)$ elevated the total WBC count (Figure 16) as well as vitB12 concentration (Figure 12) and provides the linked confirmation about the beneficial immunomodulatory response of extract on the rat.

\section{Conclusion}

Mushroom $P$. tuber-regium traditionally has been used as a nutraceutical and medicinal food supplement. The fruiting body of $P$. tuber-regium contains different mycochehemicals, protein, carbohydrate, fibers and low-fat content and high calorific value. Along with-it calorific value P. tuber- regium extract shows good antioxidant capacity, decreases the average blood sugar and glycosylated hemoglobin, elevates the vitamin D and B12 level, increases hemoglobin, RBC and WBC count of the body without producing toxicity. Thus $P$. tuber-regium can be consumed as a hypoglycaemic, haematinic agent which also boost the immune system of body and maintain the good health of the diabetic patient.

\section{Acknowledgment}

The authors acknowledge the Department of Zoology, Ranchi University, Jharkhand, India for providing research facility. Authors also acknowledge the Department of Botany, Gauhati University, Guwahati, Assam, India for great contribution to collect and identification of mushroom species.

\section{References}

1. Ferlay J, Shin HR, Bray F et al. (2010) Estimates of worldwide burden of cancer in 2008: GLOBOCAN 2008. International Journal of Cancer 127: 2893-2917. doi: 10.1002/ijc.25516.

2. Alwan A, Maclean DR, Riley LM et al. (2010) Monitoring and surveillance of chronic noncommunicable diseases: progress and capacity in high-burden countries. The Lancet 376:18611868. doi:10.1016/S0140-6736(10)61853-3.

3. Shaw JE, Sicree RA, Zimmet PZ (2010) Global estimates of the prevalence of diabetes for 2010 and 2030. Diabetes Research and Clinical Practice 87: 4 - 14. doi:10.1016/j.diabres.2009.10.007.

4. Oberg M, Jaakkola MS, Woodward A et al. (2011) Worldwide burden of disease from exposure to second-hand smoke: a retrospective analysis of data from 192 countries. The Lancet 377 (9760): 139 - 146. doi:10.1016/S0140-6736(10)61388-8.

5. Rushikesh V, Kulkarni R, Shailaja U et al. (2013) Nutritional deficiency disorders in paediatrics: an Ayurvedic perspective. International Journal of Research in Ayurveda and Pharmacy 4 (4): 605 - 607. doi:10.7897/2277-4343.04431.

6. Ullah A, Khan A, Khan I (2016) Diabetes mellitus and oxidative stress - a concise review. Saudi Pharmaceutical Journal 24: 547 - 553. doi: 10.1016/j.jsps.2015.03.013

7. Müller O, Krawinkel M (2005) Malnutrition and health in developing countries. Canadian Medical Association Journal 173 (3): 279 - 286. doi:10.1503/cmaj.050342

8. Seto KC, Fragkias M, Güneralp B, Reilly MK (2011) A metaanalysis of global urban land expansion. Plos One 6 (8): 237377. doi: 10.1371/journal.pone.0023777

9. Cohen JE (2010) Beyond population: Everyone counts in development. CGD Working Paper 220. Washington, D. C. Center for Global Development. http://www.cgdev.org/content/publi- 
cations/detail/1424318. Accessed date: January 62018.

10. Cassels S, Curran S, Kramer R (2005) Do migrants degrade coastal environments? Migration, natural resource extraction and poverty in North Sulawesi, Indonesia. Human Ecology 33: 329 - 363. doi: 10.1007/s10745-005-4142-9

11. Mittal R, Mittal CG (2013) Impact of population explosion on environment. The Nature Journal 1 (1): 1 - 5.

12. King TA (1993) Mushrooms, the ultimate health food but little research in U.S to prove it. Mushroom News 41: 29 - 46.

13. Karaman M, Vesic M, Stahl M et al. (2012) Bioactive properties of wild-growing mushroom species Ganorderma applanatum (Pers.) Pat. from Fruska Gora forest (Serbia). Ethnomedicine and Therapeutic Validation 32: 361 - 377.

14. Patel Y, Naraian R, Singh VK (2012) Medicinal properties of Pleurotus species (Oyster mushroom): a review. World Journal of Functional Plant Biology 3 (1): 1 - 12. doi: 10.5829/idosi.wjfpb.2012.3.1.303.

15. Arya V, Thakur N, Kashyap CP (2012) Preliminary phytochemical analysis of the extracts of Psidium leaves. Journal of Pharmacognosy and Phytochemistry 1 (1): 1 - 6 .

16. Dandapat S, Sinha MP (2015) Antioxidant and anti-inflammatory activity of Pleurotus tuber-regium (Rumph. ex Fr.) Singer. Advanced in Biological Researches 9 (3): 140 - 145. doi: 10.5829/idosi.abr.2015.9.3.93117.

17. Dandapat S, Kumar M, Kumar A, Sinha MP (2013) Antipathogenic efficacy of methanolic leaf extract of Cinnamomum tamala (Buch.-Ham.) and Aegle marmelos (L.) with their nutritional potentiality. The Bioscan 8 (2 Supl): 635 - 641.

18. Dandapat S, Kumar M, Ranjan R, Sinha MP (2018) Pleurotus tuber-regium (Rumph. ex Fr.) Singer a potent source of antioxidant. Balneo Research Journal 9 (3): 228 - 231. doi: 10.12680/balneo.2018.186.

19. Klein SM, Cohen G, Cederbaum AI (1991) Production of formaldehyde during metabolism of dimethyl sulphoxide by hydroxyl radical generating system. Biochemistry 20: 6006 6012. doi: 10.1021/bi00524a013.

20. OECD (2008) Organisation for Economic Co-operation and Development (OECD) guidelines for the testing chemicals Section-4. Test No. 425, Acute oral toxicity up and down procedure. pp. 1-27.

21. Oghenesuvwe EE, Ekene, Nwoke E, Lotanna AD (2014) Guidelines on dosage calculation and stock solution preparation in experimental animals’ studies. Journal of Natural Sciences Research 4 (18): 100 - 106.

22. David M, Nathan, Kuenen J et al. (2008) Heine, translating the A1c Assay in to estimated average glucose values. Diabetes Care 31 (8): 1 - 6. doi:10.2337/dc08-0545.

23. Leary FO, Samman S (2010). Vitamin B12 in health and disease. Nutrients 2 (3): 299 - 316. doi: 10.3390/nu2030299

24. Bolek-Berquist J, Elliott ME, Gangnon RE et al. (2009) Use of a questionnaire to assess vitamin D status in young adults. Pub- lic Health Nutrition 12 (2): $236 \quad-243 . \quad$ doi: 10.1017/S136898000800356X.

25. Mycobank (1951) Pleurotus tuber-regium (Fr.) Singer, Lilloa 22: 271 (1951): MB\#303985.http://www.mycobank.org/. Accessed date: 26 December 2018.

26. EOL (2018) Pleurotus tuber-regium - Details - Encyclopedia of Life. http://eol.org/pages/11463022/details. Accessed date: 17 January 2019.

27. Onuoha CI, Obi-Adumanya GA (2010) Proximate analysis of Pleurotus tuber-regium (Singer) grown on the different substrates. Researcher 2 (10): 7 - 11.

28. Jonathan SG, Adeoyo OR (2011) Collection, morphological characterization and nutrient profile of some wild mushrooms from Akoko, Ondo state, Nigeria. Natural Product of Indian Journal 7 (3): $128-136$.

29. Singh S, Lal AA, Simon S, Ramteke PW (2017) Efficacy of selected botanicals on biochemical constituents of white button mushroom Agaricus bisporus (Lange) Imbach. Journal of Pharmacognosy and Phytochemistry 6 (5): 2070 - 2076.

30. Reusch W (2013) Infrared spectroscopy. IOCD to assist in capacity building in chemical education. https://www2.chemistry.msu.edu/ faculty/reusch/virttxtjml/ spectrpy/ infrared/infrared.htm. Accessed date: 17 June 2018.

31. Libertext C (2014) Infrared spectroscopy absorption table. https://chem.libretexts.org/Reference/Reference_Tables/Spectroscopic_Parameters/Infrared_Spectroscopy_Absorption_Table. Accessed: 25 March 2018.

32. Wikipedia (2018) Infrared spectroscopy correlation table. https://en.wikipedia.org/ wiki/Infrared_spectroscopy_correlation_table. Accessed date: 7 November 2018.

33. Radzki W, Kalbarczyk J (2010) Water soluble polysaccharides content in three species of edible and medicinal mushrooms: Lentinula edodes, Pleurotus ostreatus, Agaricus blazei. Herba Polonica 56 (4): 31 - 38. http://www.herbapolonica.pl/articles/view/97

34. Udu-Ibiam OE, Ogbu O, Ibiam UA et al. (2014) Phytochemical and antioxidant analyses of selected edible mushrooms, ginger and garlic from Ebonyi state, Nigeria. Journal of Pharmaceutical and Biological Sciences 9 (3): 86 - 91.

35. Ozen T, Collu Z, Korkmaz H (2010) Antioxidant properties of Urtica pilulifera root, seed, flower, and leaf extract. Journal of Medicinal Food 13 (5): 1224 - 1231. doi: 10.1089/jmf.2009.1303

36. Dandapat S, Kumar M, Sinha MP (2014) Pharmacological and phytochemical screening of Aegle marmelos (L.) and Cinnamomum tamala (Buch.-Ham.) leaves for therapeutic efficacy. Mid-East Journal of Scientific Research 22 (5): 626 - 632.

37. Imam MU, Zhang S, Ma J et al. (2017) Antioxidants mediate both Iron homeostasis and oxidative stress. Nutrients 9 (671): 1 - 19. doi:10.3390/nu9070671

38. Prabu M, Kumuthakalavalli R (2016) Antioxidant activity of 
oyster mushroom (Pleurotus florida [Mont.] Singer) and milky mushroom (Calocybe indica $\mathrm{P}$ and $\mathrm{C}$ ). International Journal of Current Pharmaceutical Research 8 (3): 48 - 51.

39. Sudha G, Vadivukkarasi S, Shree RBI, Lakshmanan P (2012) Antioxidant activity of various extracts from an edible mushroom Pleurotus eous. Food Science and Biotechnology 21 (3): 661 - 668. doi: 10.1007/s10068-012-0086-1.

40. Dandapat S, Kumar M, Sinha MP (2014) Therapeutic efficacy of Cinnamomum tamala (Buch.-Ham.) and Aegle marmelos (L.) leaf. Balneo Research Journal (5) 3: 113 - 122. doi:10.12680/balneo.2014.1071.

41. Dandapat S, Sinha MP, Kumar M, Jaggi Y (2015) Hepatoprotective efficacy of medicinal mushroom Pleurotus tuber-regium. Environmental and Experimental Biology 13: 103 - 108.

42. Okwulehie IC, Odunze ET (2004) Evaluation of the mycochemical and mineral composition of some tropical edible mushroom. Journal of Sustainable Agriculture and the Environment 6 (1): 63 - 70.

43. Thatoi H, Singdevsachan SK (2014) Diversity, nutritional composition and medicinal potential of Indian mushrooms: a review. African Journal of Biotechnology 13 (4): 523 - 545. doi: 10.5897/AJB2013.13446

44. Wani BA, Bodha RH, Wani AH (2010) Nutritional and medicinal importance of mushrooms. Journal of Medicinal Plants Research 4 (24): 2598 - 2604. doi: 10.5897/JMPR09.565

45. Ghazanfari Z, Haghdoost AA, Alizadeh SM et al. (2010) A comparison of HbA1c and fasting blood sugar tests in general population. International Journal of Preventive Medicine 1(3): $187-194$.

46. Gandhi RG, Sasikumar P (2012) Antidiabetic effect of Merremia emarginata Burm. F. in streptozotocin induced diabetic rats. Asian Pacific Journal of Tropical Biomedicine 2 (4): 281 286. doi: 10.1016/S2221-1691(12)60023-9.

47. Silva DDD, Rapior S, Hyde KD, Bahkali AH (2012) Medicinal mushrooms in prevention and control of diabetes mellitus. Fungal Diversity 56: 1 - 29. doi: 10.1007/s13225-012-0187-4

48. Abdirahman YA, Juma KK, Makori WA et al. (2015) Blood glucose lowering effect and safety of the aqueous leaf extracts of Zanha africana. Pharmaceutica Analytica Acta 6 (9): 1 - 9. doi: 10.4172/2153-2435.1000422.

49. Brahmachari G (2011) Bio-flavonoids with promising antidiabetic potentials: A critical survey. In: Tiwari KV, Mishra BB, Opportunity, challenge and scope of natural products in medicinal chemistry (2nd Edn). Kerala India, Research Signpost. Pp. $411-431$.

50. Odoh UE, Ezugwu CO (2012) Anti-diabetic and toxicological studies of the alkaloids of Acanthus montanus (Acanthaceae) leaf. Planta Medica 78 (11): CL70. doi: 10.1055/s-00321320305.

51. Liu X, Kim JK, Li Y et al. (2005) Tannic acid stimulates glucose transport and inhibits adipocyte differentiation in 3T3-L1 cells.
Journal of Nutrition 135 (2): 165-171. doi:10.1093/jn/135.2.165

52. Chen KJ, Zhang WP (1987) Advances on antiageing herbal medicines in China. Traditional Chinese medicine 1: 309-330.

53. Jayasuriya WJABN, Suresh TS, Abeytunga DTU et al. (2012) Oral hypoglycemic activity of culinary-medicinal mushrooms Pleurotus ostreatus and P. cystidiosus (higher basidiomycetes) in normal and alloxan-induced diabetic wistar rats. International Journal of Medicinal Mushrooms 14 (4): 347 - 355.

54. Khatun S, Islam A, Guler P et al. (2013) Hypoglycemic activity of a dietary mushroom Pleurotus florida on alloxan induced diabetic rats. Biology Diversity Conservation 6 (2): 91-96.

55. Mattila PK, Konko M, Eurola J et al. (2000) Contents of vitamins, mineral elements and some phenolic compounds in the cultivated mushrooms. Journal of Agricultural and Food Chemistry 49: 2343 - 2348. doi: 10.1021/jf001525d.

56. Manzi P, Marconi S, Aguzzi A, Pizzoferrato L (2004) Commercial mushrooms: nutritional quality and effect of cooking. Food Chemistry 84: 201 - 206. doi: 10.1016/S0308-8146(03)002024

57. Abdelghany EMA, Ibrahim AN (2015) The protective effect of vitamin $\mathrm{D}$ on cerebral infarction in rats received high fructose diet. International Archives of Integrated Medicine 2 (11): 6 14.

58. Jasinghe VJ, Perera OC, Barlow PJ (2005) Bioavailability of vitamin D2 from irradiated mushrooms: an in vivo study. British Journal of Nutrition 93 (6): 951 - 955.

59. Partearroyo T, Ubeda N, Montero A et al. (2013) Vitamin B12 and folic acid imbalance modifies NK cytotoxicity, lymphocytes B and lymphoprolipheration in aged rats. Nutrients 5: 4836 - 4848. doi:10.3390/nu5124836

60. Shawabkeh MJA, Jamal AA (2018) Effect of rosemary on fasting blood glucose, hemoglobin A1c and vitamin B12 in healthy person and type 2 diabetic patients taking glucomid or/and metformin. National Journal of Physiology, Pharmacy and Pharmacology 8 (1): 1 - 4. doi: 10.5455/njppp.2018.8.0723812102017

61. Oyetayo VO, Oyetayo FL (2007) Haematological parameters of rats fed mushroom, Pleurotus sajor-caju diets and orogastrically dosed with probiotic Lactobacillus fermentum OVL. International Journal of Probiotics and Prebiotics 2(1): 39 - 42.

62. Promise N, Agomuo EN, Uloneme GC et al. (2014) Effect of Phyllanthus amarus leaf extract on alterations of haematological parameters in Salmonellae typhi infested wistar albino rats. Scientific Research and Essays 9 (1): 7 - 12. doi: 10.5897/SRE2013.5611.

63. Ekundayo FO, Ayodele BB, Akinyele BJ (2014) Biosafety assessment of Pleurotus ostreatus and $P$. pulmonarius cultivated on bonnylight crude oil contaminated soils. International Research Journal of Biological Sciences 3 (6):18 - 23.

64. Erhunmwunse NO, Ejoh S, Ekaye SO (2017) Efficiency of Pleurotus florida dietary supplement in reducing Cadmium toxicity in Albino rat (Rattus norvegicus). Nigarian Annals of Na- 
tural Sciences $16(1): 38-42$.

65. Arika WM, Nyamai DW, Musila MN et al. (2016) Hematological markers of in vivo toxicity. Journal of Hematology and Thromboembolic Diseases and Disorders 4 (2): 1 - 7. doi: 10.4172/2329-8790.1000236.

66. Aslinia F, Mazza JJ, Yale SH (2006) Megaloblastic anemia and other causes of macrocytosis. Clinical Medicine and Research 4: $236-241$.

67. Ulukoy G, Baba E, Ontaş C (2016) Effect of oyster mushroom, Pleurotus ostreatus, extract on hemato-immunological parameters of Rainbow trout, Oncorhynchus mykiss. Journal of the World Aquaculture Society 47 (5): 676 - 684. doi 10.1111/jwas.12318.
68. Oyetayo VO, Oyetayo FL (2005) Preliminary study of the health promoting potentials of Lactobacillus fermentum OVL and Pleurotus sajor-caju administered to rats. Pakistan Journal of Nutrition 4 (2): $73-77$.

69. Hill MJ (1997) Intestinal flora and vitamin synthesis. European Association of Preventive Cardiology 6 Suppl 1 (1): 43 - 45.

70. LeBlanc JG, Milani C, deGiori GS et al. (2013) Bacteria as vitamin suppliers to their host: a gut microbiota perspective. Current Opinion in Biotechnology 24 (2): 160 - 168. doi: 10.1016/j.copbio.2012.08.005. 
This page is intentionally left blank. 